\title{
Phylogenetic diversity of cultured bacteria from prevalent species of corals around Samae San island, Thailand
}

\author{
Dewi Embong Bulan ${ }^{\mathrm{a}, \mathrm{b}}$, Suchana Chavanich ${ }^{\mathrm{a}}$, Voranop Viyakarn ${ }^{\mathrm{a}}$, Naraporn Somboonna ${ }^{\mathrm{c}, *}$ \\ ${ }^{a}$ Reef Biology Research Group, Department of Marine Science, Faculty of Science, Chulalongkorn \\ University, Bangkok 10330 Thailand \\ b Department of Aquatic Resources Management, Faculty of Fisheries and Marine Science, Mulawarman \\ University, Samarinda 75119 Indonesia \\ c Department of Microbiology, Faculty of Science, Chulalongkorn University, Bangkok 10330 Thailand
}

*Corresponding author, e-mail: Naraporn.S@chula.ac.th

Received 16 Jan 2019

Accepted $27 \mathrm{Feb} 2020$

\begin{abstract}
Predominant corals of Samae San island, Thailand, including Acropora humilis, Acropora millepora, Porites lutea and Platygyra sinensis, were cultured and identified for bacterial species by 16S rRNA gene sequencing. Of all corals, dominant cultured bacteria were Firmicutes (46.75\%), Proteobacteria (34.60\%), Actinobacteria (17.18\%) and Bacteriodetes (1.47\%). Firmicutes such as Staphylococcus, Bacillus and Sediminibacillus was relatively most abundant ( $\sim 50 \%$ ), except in $P$. sinensis that Proteobacteria was more abundant. Over culture temperature range of $20-50{ }^{\circ} \mathrm{C}$, different bacterial species were grown (ANOVA, $p<0.05$ ). Coral $P$. lutea and A. humilis associated bacteria were able to be cultured at the highest temperature $\left(45^{\circ} \mathrm{C}\right)$, followed by coral A. millepora $\left(40^{\circ} \mathrm{C}\right)$ and $P$. sinensis $\left(35^{\circ} \mathrm{C}\right)$ bacteria. The high-temperature cultured bacteria were mostly Bacillus such as Bacillus amyloliquefaceins. Multiple sequence alignment and phylogeny relationship of the bacterial species from these four corals showed that, for Firmicutes and Proteobacteria, the bacterial species isolated from coral P. lutea, A. humilis and A. millepora rather shared clades. Overall, the coral Acropora demonstrated more diversity of bacterial species than coral Porites. The culturing attempt at high temperature allowed additional bacterial species findings.
\end{abstract}

KEYWORDS: bacterial diversity, 16S rRNA gene sequencing, coral-associated bacteria, Thailand

\section{INTRODUCTION}

Coral reefs are well-known resources to support large, biodiverse communities of organisms and microorganisms both in the marine ecosystem and on Earth. For instance, coral reefs function as shelters for many lives and are nutrient-rich habitat. Coral-associated bacteria were reported either on a coral's surface, a calcium carbonate skeleton, or its inside hollow $[1,2]$. The co-living between corals and bacteria shares mutual benefits, including but not limited to, exchange of nutrients (e.g., corals provide nutrient-rich resources while bacteria are initial producers and final recyclers of organic food chains) and support of coral resistance to high temperature and pathogen (e.g., bacterial antioxidants and secondary metabolites) $[3,4]$. Hence, specific bacteria were reported to correlate with diseaseresistant corals [3,5-7], yet study on cultivation of the coral-associated bacteria from prevalent species of corals in Samae San island, Thailand, the region where coral reefs are abundant [8], had been limited. Samae San island locates in the east Gulf of Thailand. This study cultured and identified coral bacteria in all prevalent species of corals in Samae San island including Acropora humilis, Acropora millepora, Porites lutea and Platygyra sinensis, and analyzed their 16S rRNA gene sequence alignment and phylogenetic relationship. Additionally, as global warming (thus rising water temperature) is a cause of coral bleaching worldwide during the last decade, we as well described the cultured coralassociated bacteria that could survive at relatively high temperature (up to $50^{\circ} \mathrm{C}$ ). This supports the better understanding of the bacterial diversity and coral species during high temperature, and the collection of live bacterial isolates are also important for future physiological studies.

Previously, culture and culture-independent (metagenomics) studies reported that coral- 
associated bacteria are sometimes specific to coral species and environments $[1,9,10]$. Given cultivation allows to obtain live bacteria collection for physiological and functional studies $[11,12]$ and no bacteria collection associated with coral species and high temperature had been cultivated before in Samae San island coral reefs, thus signifying the bacteria collection in this study.

\section{MATERIALS AND METHODS}

\section{Sample collections}

Healthy corals of A. humilis, A. millepora, P. lutea and $P$. sinensis were collected around Samae San island on April 28, 2014 (Fig. 1). Of each coral specie, 3 independent samples of $2 \mathrm{~cm}$ diameter size were collected in separate sterile bags and transported on ice immediately to laboratory.

\section{Cultivation of bacteria}

The protocols of cultivation followed established protocols [13] with some modifications. Each coral sample was ground and $1 \mathrm{~g}$ was serially diluted from $10^{-1}-10^{-5}$ with $0.2 \mu \mathrm{m}$ filtered-sterile seawater. Each dilution $(100 \mu l)$ was spread onto a seawater nutrient agar (SNA; autoclaved seawater supplemented with $0.3 \%$ beef extract and $0.5 \%$ peptone in $1.5 \%$ agar) and incubated under aerobic condition at $20,25,30,35,40,45$ and $50^{\circ} \mathrm{C}$ for 2 weeks. Hence, each set of experiment consisted of 5 serial dilutions, 7 incubation conditions and 2 independent replicate sets. Total colony count represents the number of cultured bacteria in colony forming unit (CFU) per $\mathrm{g}$ of coral. Then, colonies of different morphologies were transferred to another SNA for streaking to isolate colonies. Gram stain and optical microscopic record were performed on isolated colonies for confirmation.

\section{S rRNA gene amplification and sequencing}

Single colony from each isolate was picked into a 25- $\mu$ l PCR reaction, comprising $1 \times$ EmeraldAmp GT PCR Master Mix (TaKaRa, Shiga, Japan), $0.3 \mu \mathrm{M}$ of each of the forward and reverse primers and template (single colony or 50 ng of DNA). If colony PCR did not yield result, the isolate colony was cultured in SN broth, and the bacterial genome was extracted using GF1-Bacterial DNA Extraction Kit (Vivantis, California, USA). The extracted DNA was determined for the concentration and the purity using nanodrop spectrophotometer, and $50 \mathrm{ng}$ of the DNA was used in PCR. Full-length 16S rRNA gene is amplified using universal primers $27 \mathrm{~F}\left(5^{\prime}\right.$ AGAGTTTGATCCTGGCTCAG- $3^{\prime}$ ) and 1492R ( $5^{\prime}$ GGTTACCTTGTTACGACTT- $\left.3^{\prime}\right)[14,15]$. The PCR thermocycling conditions were $95^{\circ} \mathrm{C} 4 \mathrm{~min}, 30-35$ cycles of $94^{\circ} \mathrm{C} 1 \mathrm{~min}, 55^{\circ} \mathrm{C} 1 \mathrm{~min}$ and $72^{\circ} \mathrm{C} 2 \mathrm{~min}$, followed by $72^{\circ} \mathrm{C} 10 \mathrm{~min}$. An amplicon corresponding to the full-length 16S rRNA gene (1500

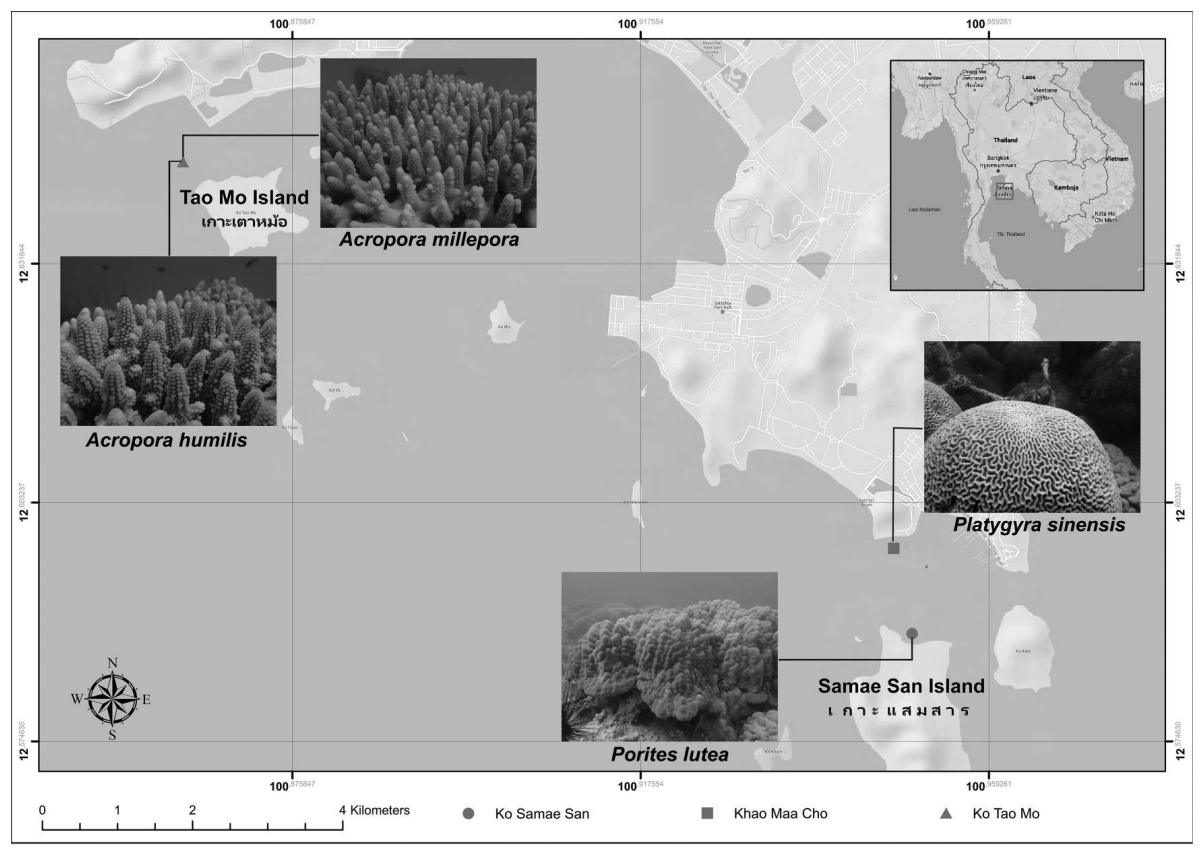

Fig. 1 Photograph of coral samples and study sites. 
base pairs) was visualized by $1.5 \%$ agarose gel electrophoresis, purified and sequenced using Sanger's sequencer ABI3730XL at Macrogen Inc., Korea.

Bacteria species identification, multiple sequence alignment, and phylogenetic analysis

Ambiguous nucleotides on both ends of raw sequences were trimmed by manual inspection of electropherographs showing mixed peaks of nucleotides. Trimmed sequences were identified for species by BLASTN against NCBI non-redundant database with $\leqslant 10^{-4}$ E-value cutoff, unless specified otherwise [16]. The cultured bacterial sequences and reference sequences were also aligned using CLUSTALX [17], and a neighbor joining tree with 1000 bootstrap replicates was constructed using MEGA version 7 [18], in order to get the glimpse on the putative distance between the cultured bacterial species and the references. A correlation between coral species and a temperature in which the different bacterial diversity were cultured was determined by ANOVA statistic ( $p$ values).

\section{RESULTS}

\section{Total colony count}

The number of cultured colonies in CFUs (0.6$3.8 \times 10^{3} \mathrm{CFU} / \mathrm{g}$ ), including the number of different colony morphologies (7-27 cultured bacterial IDs), varied by both coral species and culture temperatures. A. humilis and P. lutea showed the highest total bacterial count, followed by $P$. sinensis and A. millepora, respectively. The number of different morphologies (cultured bacterial diversity) followed the same order as the total bacterial count, which is A. humilis, P. lutea, P. sinensis and A. millepora (Table 1 ). For culture temperature, $30-35^{\circ} \mathrm{C}$ allowed the maximum total bacterial counts and the number of bacterial diversity. $P$ sinensis and A. millepora demonstrated the relatively narrow temperature growth range whereas $A$. humilis and P. lutea could be cultured at up to $45^{\circ} \mathrm{C}(0.1-$ $0.4 \times 10^{3} \mathrm{CFU} / \mathrm{g}$ coral and $1-2$ different colony morphologies) (Table 1).

\section{Identification of bacterial species}

Unique colony morphologies of each coral species were analyzed by gram stain (gram-positive or gram-negative) and optical microscopy to confirm distinct cell morphology. The confirmed distinct isolates with at least $9 \%$ relative abundance were sequenced and identified for species using BLASTN (Table S1). Most bacterial species belonged to phyla
Table 1 Total colony counts in CFUs/g coral and the number of different morphology colonies from four coral species cultured at different temperatures.

\begin{tabular}{|c|c|c|c|}
\hline Sample & Temp. $\left({ }^{\circ} \mathrm{C}\right)$ & $\mathrm{CFU} / \mathrm{g}$ & No. isolate \\
\hline \multirow[t]{7}{*}{ A. humilis } & 20 & 0 & 0 \\
\hline & 25 & 2200 & 9 \\
\hline & 30 & 3400 & 17 \\
\hline & 35 & 2700 & 14 \\
\hline & 40 & 1100 & 4 \\
\hline & 45 & 100 & 1 \\
\hline & 50 & 0 & 0 \\
\hline \multirow[t]{7}{*}{ A. millepora } & 20 & 0 & 0 \\
\hline & 25 & 500 & 4 \\
\hline & 30 & 600 & 5 \\
\hline & 35 & 500 & 7 \\
\hline & 40 & 100 & 1 \\
\hline & 45 & 0 & 0 \\
\hline & 50 & 0 & 0 \\
\hline \multirow[t]{7}{*}{ P. lutea } & 20 & 0 & 0 \\
\hline & 25 & 2700 & 27 \\
\hline & 30 & 2600 & 22 \\
\hline & 35 & 3200 & 27 \\
\hline & 40 & 700 & 4 \\
\hline & 45 & 400 & 2 \\
\hline & 50 & 0 & 0 \\
\hline \multirow{7}{*}{ P. sinensis } & 20 & 0 & 0 \\
\hline & 25 & 1900 & 6 \\
\hline & 30 & 1900 & 6 \\
\hline & 35 & 3800 & 11 \\
\hline & 40 & 0 & 0 \\
\hline & 45 & 0 & 0 \\
\hline & 50 & 0 & 0 \\
\hline
\end{tabular}

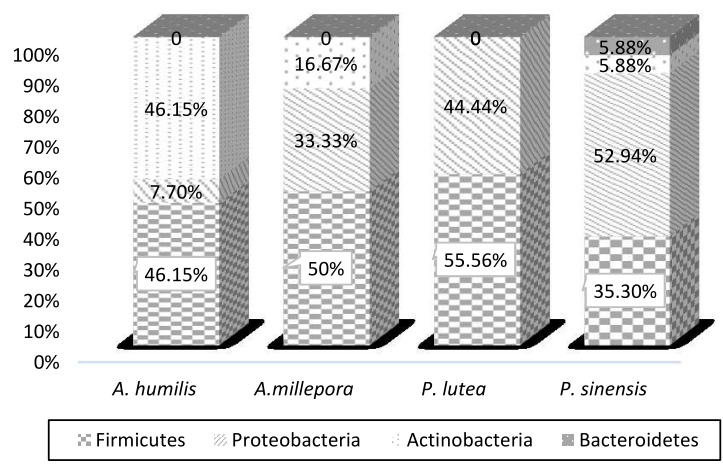

Fig. 2 Percent distribution of cultured bacteria at phylum level.

Firmicutes (35.30-46.15\%), Proteobacteria (7.70$52.94 \%)$ and Actinobacteria (0-46.15\%), except P. sinensis that also contain species in phylum Bacteriodetes for $5.88 \%$ (Fig. 2). Calculating the diversity index via phylum richness and phylum evenness (a 
relative distribution of each phylum) showed that A. millepora and $P$. sinensis provided the highest bacterial diversity, although the minimal number of cultured bacterial IDs was from A. millepora (6 different species) (Table S1). For differences in the cultured temperatures, ANOVA statistic indicated an association between temperature and the bacterial diversity $(p<0.05)$.

In addition, the cultured bacteria and the reference sequences were aligned to observe pairwise distances among sequences (Table S2). In Firmicutes, the cultured bacteria from $P$. sinensis showed a relatively separate clade compared with those in the other three coral species, which were clustered at $76 \%$ confidence. Shared bacterial species among these three coral species included unidentified species of Staphylococcus (i.e., Staphylococcus sp.), Staphylococcus epidermidis and Bacillus amyloliquefaciens (Fig. S1a). For bacteria in phyla Proteobacteria and Actinobacteria, the P. sinensisassociated bacteria showed overlapped similarities (Table S2: smaller number of base substitutions and Fig. S1b: shared clades of trees). Nevertheless, sequences in this study were from a single sequencing reaction (700 base pairs), so the alignment and the phylogenetic relatedness compared with the reference sequences remained elusive.

\section{DISCUSSION}

Diverse bacterial communities were reported on coral reefs worldwide $[2,19]$. This report represented the first cultured coral-associated bacteria diversity from prevalent coral species (A. humilis, A. millepora, $P$. lutea and P. sinensis) in Samae San island. Different coral species contained diversity and frequencies of bacteria (2750 CFUs/g coral), and bacteria from certain coral species were able to survive and grow at high temperature (i.e., $A$. $h u-$ milis and $P$. lutea). These bacteria could be important for future physiological studies that involve temperature resistance.

Most cultured bacteria were gram-positive, supporting a general gram stain type reported in marine elsewhere [13] because gram-positive bacteria cell membrane with thick peptidoglycan layer allow bacteria to be more resistant than gram-negative bacteria cell membrane. Identified species of Firmicutes were capable of forming endospore (i.e., Bacillus sp.), which is a resistant form of bacteria to a harsh environment such as hot and dry. Additionally, Bacillus and Actinobacteria species are producers of antimicrobial compounds such as bacitracin and polymyxin B that might help protect corals from pathogenic bacteria $[10,20,21]$. Supportively, Liang et al [22] reported that Acropora had the relatively high bacteria diversity, yet coral pathogen bacteria detected, thus highlighting a relationship between this coral-associated bacteria community with the coral resistance to pathogens.

However, our reported diversity of cultured bacteria was far fewer than that published by metagenomics combined next generation sequencing (culture-independent) methods, although the finding of high prevalence of proteobacteria remains common $[19,23]$. The far fewer number by cultured method was consistent with many publications that compared the cultured and culture-independent methods [13].

\section{Appendix A. Supplementary data}

Supplementary data associated with this article can be found at http://dx.doi.org/10.2306/ scienceasia1513-1874.2020.018.

Acknowledgements: The authors thanked Aira Angeline Ko and Jikka Nealiga for laboratory help. This research was supported by Thailand Research Fund (RSA6180046) and the 90th Anniversary of Chulalongkorn University Fund.

\section{REFERENCES}

1. Bourne DG, Munn CB (2005) Diversity of bacteria associated with the coral Pocillopora damicornis from the Great Barrier Reef. Environ Microbiol 7, 1162-1174.

2. Koren O, Rosenberg E (2006) Bacteria associated with mucus and tissues of the coral Oculina patagonica in summer and winter. Appl Environ Microbiol 72, 5254-5259.

3. Rosenberg E, Koren O, Reshef L, Efrony R, ZilberRosenberg I (2007) The role of microorganisms in coral health, disease and evolution. Nat Rev Micro 5, 355-362.

4. Schmidt EW, Obraztsova AY, Davidson SK, Faulkner DJ, Haygood MG (2000) Identification of the antifungal peptide-containing symbiont of the marine sponge Theonella swinhoei as a novel $\delta$ proteobacterium, Candidatus Entotheonella palauensis. Mar Biol 136, 969-977.

5. Wegley L, Edwards R, Rodriguez-Brito B, Liu H, Rohwer F (2007) Metagenomic analysis of the microbial community associated with the coral Porites astreoides. Environ Microbiol 9, 2707-2719.

6. Kimes NE, Van Nostrand JD, Weil E, Zhou J, Morris PJ (2010) Microbial functional structure of Montastraea faveolata, an important Caribbean reef-building coral, differs between healthy and yellow-band diseased colonies. Environ Microbiol 12, 541-556. 
7. Roder C, Arif C, Bayer T, Aranda M, Daniels C, Shibl A, Chavanich S, Voolstra CR (2014) Bacterial profiling of white plague disease in a comparative coral species framework. ISME J 8, 31-39.

8. Phongsuwan N, Chankong A, Yamarunpatthana C, Chansang H, Boonprakob R, Petchkumnerd P, Thongtham N, Paokantha S, et al (2013) Status and changing patterns on coral reefs in Thailand during the last two decades. Deep Sea Res II: Top Stud Oceanograp 96, 19-24.

9. Frias-Lopez J, Zerkle AL, Bonheyo GT, Fouke BW (2002) Partitioning of bacterial communities between seawater and healthy, black band diseased, and dead coral surfaces. Appl Environ Microbiol 68, 2214-2228.

10. Rohwer F, Seguritan V, Azam F, Knowlton N (2002) Diversity and distribution of coral-associated bacteria. Mari Ecol Prog Ser 243, 1-10.

11. Zengler K, Toledo G, Rappé M, Elkins J, Mathur EJ, Short JM, Keller M (2002) Cultivating the uncultured. PNAS 99, 15681-15686.

12. Pettit RK (2011) Culturability and secondary metabolite diversity of extreme microbes: expanding contribution of deep sea and deep-sea vent microbes to natural product discovery. Mar Biotechnol 13, $1-11$.

13. Khitmoh K, Wilantho A, Wongsawaeng D, Tongsima S, Somboonna N (2017) 16S rRNA gene sequencing assessment of the prokaryotic communities in the southeast Andaman Sea, Thailand and potential environmental alerts. Chiang Mai J Sci 44, 15-28.

14. Weisburg WG, Barns SM, Pelletier DA, Lane DJ (1991) 16S ribosomal DNA amplification for phylogenetic study. J Bacteriol 173, 697-703.

15. Reysenbach AL, Giver LJ, Wickham GS, Pace NR
(1992) Differential amplification of rRNA genes by polymerase chain reaction. App Environ Microbiol 58, 3417-3418.

16. Altschul SF, Gish W, Miller W, Myers EW, Lipman DJ (1990) Basic local alignment search tool. J Mol Biol 215, 403-410.

17. Thompson JD, Gibson TJ, Plewniak F, Jeanmougin F, Higgins DG (1997) The CLUSTAL_X windows interface: flexible strategies for multiple sequence alignment aided by quality analysis tools. Nucleic Acids Res 25, 4876-4882.

18. Tamura K, Stecher G, Peterson D, Filipski A, Kumar S (2013) MEGA6: molecular evolutionary genetics analysis version 6.0. Mol Biol Evol 30, 2725-2729.

19. Rohwer F, Breitbart M, Jara J, Azam F, Knowlton N (2001) Diversity of bacteria associated with the Caribbean coral Montastraea franksi. Coral Reefs 20, 85-91.

20. Wiese J, Thiel V, Nagel K, Staufenberger T, Imhoff JF (2009) Diversity of antibiotic active bacteria associated with the brown alga Laminaria saccharina from the Baltic Sea. Mari Biotech 11, 287-300.

21. Shnit-Orland M, Kushmaro A (2009) Coral mucusassociated bacteria: a possible first line of defense. FEMS Microbiol Ecol 67, 371-380.

22. Liang J, Yu K, Wang Y, Huang X, Huang W, Qin Z, Pan Z, Yao Q, et al (2017) Distinct bacterial communities associated with massive and branching Scleractinian corals and potential linkages to coral susceptibility to thermal or cold stress. Front Microbiol 8, ID 979.

23. Bulan DE, Wilantho A, Krainara P, Viyakarn V, Chavanich S, Somboonna N (2018) Spatial and seasonal variability of reef bacterial communities in the upper Gulf of Thailand. Front Mar Sci 29, ID 441. 


\section{Appendix A. Supplementary data}
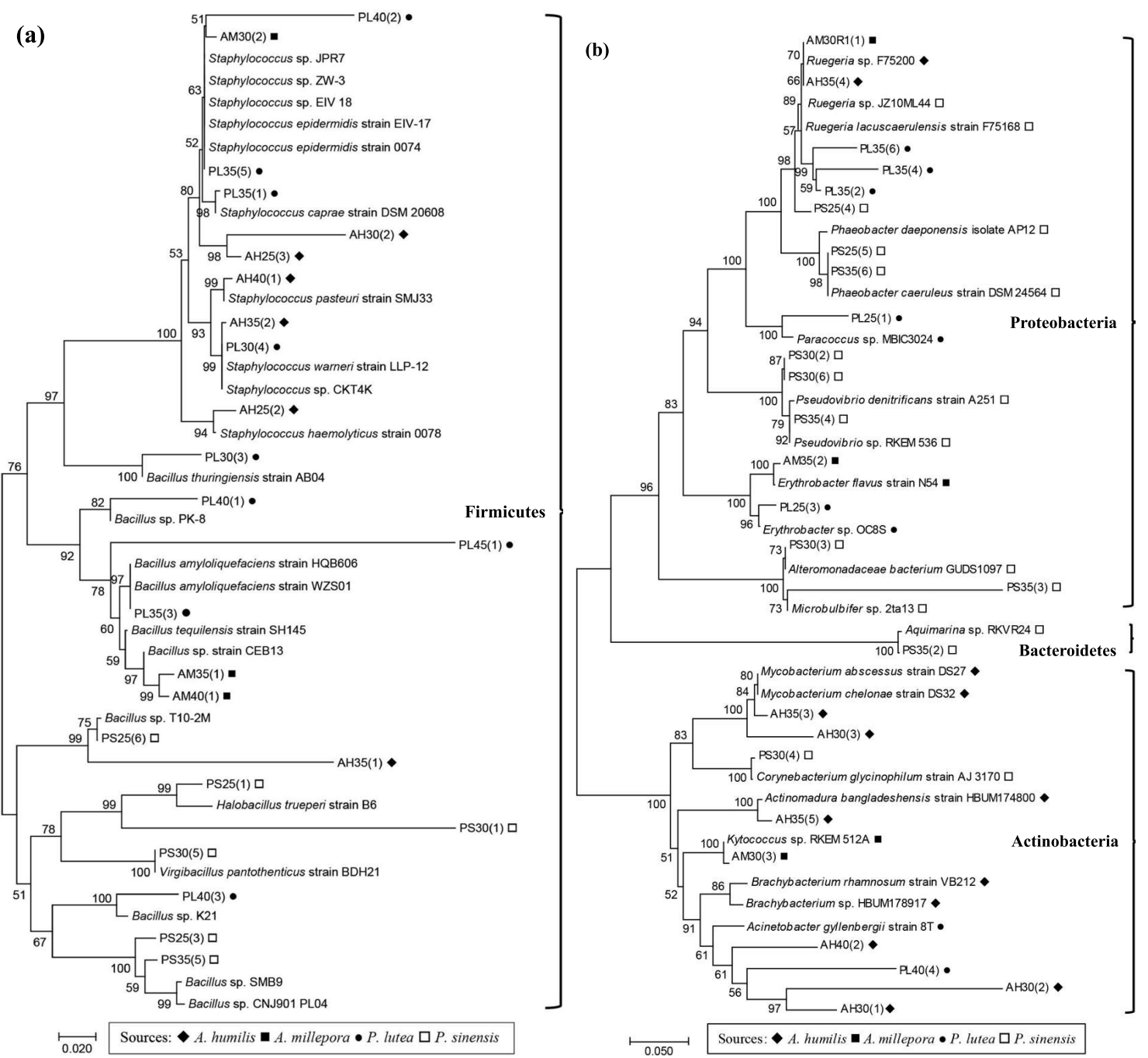

Fig. S1 Neighbor-joining tree of cultured bacterial IDs and their reference species in phyla (a) Firmicutes and (b) Proteobacteria, Actinobacteria and Bacteroidetes. Number at node represents percent bootstrap replicates (cluster confidence), and $<50 \%$ bootstrap replicates were not displayed. A bar at a bottom of the tree represents a unit of genetic distance. 
Table S1 Species and phylum identification by BLASTN.

\begin{tabular}{|c|c|c|c|c|}
\hline ID & GenBank No. & Species identification & Nucleotide (\%) & Phylum \\
\hline \multicolumn{5}{|c|}{ A. humilis coral } \\
\hline $\mathrm{AH} 25(1)$ & KP236214.1 & Staphylococcus haemolyticus strain 0078 & 100 & Firmicutes \\
\hline $\mathrm{AH} 25(2)$ & KU821699.1 & Staphylococcus warneri strain LLP-12 & 99 & Firmicutes \\
\hline $\mathrm{AH} 25(3)$ & KU323914.1 & Staphylococcus sp. ZW-3 & 100 & Firmicutes \\
\hline $\mathrm{AH} 30(1)$ & LC125158.1 & Brachybacterium rhamnosum strain: VB-2.1.2 & 99 & Actinobacteria \\
\hline AH30(2) & KR906081.1 & Brachybacterium sp. HBUM178917 & 95 & Actinobacteria \\
\hline АH30(3) & KU362955.1 & Mycobacterium abscessus strain DS27 & 97 & Actinobacteria \\
\hline AH35(1) & AB617555.1 & Bacillus sp. T10-2M & 91 & Firmicutes \\
\hline AH35(2) & KU821699.1 & Staphylococcus warneri strain LLP-12 & 100 & Firmicutes \\
\hline AH35(3) & KU362960.1 & Mycobacterium chelonae strain DS32 & 99 & Actinobacteria \\
\hline $\mathrm{AH} 35(4)$ & HQ908757.1 & Ruegeria sp. F75200 & 99 & Proteobacteria \\
\hline AH35(5) & EU841643.1 & Actinomadura bangladeshensis strain HBUM174800 & 99 & Actinobacteria \\
\hline $\mathrm{AH} 40(1)$ & KT036409.1 & Staphylococcus pasteuri strain SMJ33 & 99 & Firmicutes \\
\hline $\mathrm{AH} 40(2)$ & LT547841.1 & Micrococcus yunnanensis isolate 54 SP633 & 95 & Actinobacteria \\
\hline \multicolumn{5}{|c|}{ A. millepora coral } \\
\hline AM30(1) & HQ908678.1 & Ruegeria lacuscaerulensis strain F75168 & 99 & Proteobacteria \\
\hline $\operatorname{AM} 30(2)$ & FJ613575.1 & Staphylococcus epidermidis strain EIV-17 & 99 & Firmicutes \\
\hline $\operatorname{AM} 30(3)$ & KU198778.1 & Kytococcus sp. RKEM 512A & 98 & Actinobacteria \\
\hline AM35(1) & KC172053.1 & Bacillus tequilensis strain SH145 & 98 & Firmicutes \\
\hline $\mathrm{AM} 35(2)$ & KJ004620.1 & Erythrobacter flavus strain N54 & 99 & Proteobacteria \\
\hline $\operatorname{AM} 40(1)$ & KX681803.1 & Bacillus sp. strain CEB13 & 98 & Firmicutes \\
\hline \multicolumn{5}{|c|}{ P. lutea coral } \\
\hline PL25(1) & AB008115.1 & Paracoccus sp. MBIC3024 & 99 & Proteobacteria \\
\hline PL25(2) & HQ288801.1 & Erythrobacter nanhaisediminis strain F75112 & 99 & Proteobacteria \\
\hline PL25(3) & AB429073.1 & Erythrobacter sp. OC8S & 99 & Proteobacteria \\
\hline PL30(1) & HQ439523.1 & Ruegeria sp. MR31c & 100 & Proteobacteria \\
\hline PL30(2) & FJ613576.1 & Staphylococcus sp. EIV-18 & 96 & Firmicutes \\
\hline PL30(3) & KX245016.1 & Bacillus thuringiensis strain AB04 & 100 & Firmicutes \\
\hline PL30(4) & KU051664.1 & Staphylococcus sp. CKT4K & 100 & Firmicutes \\
\hline PL35(1) & NR_119252.1 & Staphylococcus caprae strain DSM 20608 & 99 & Firmicutes \\
\hline PL35(2) & HQ9̄908705.1 & Ruegeria lacuscaerulensis strain F77045 & 99 & Proteobacteria \\
\hline PL35(3) & KX665550.1 & Bacillus amyloliquefaciens strain WZS01 & 99 & Firmicutes \\
\hline PL35(4) & KU560505.1 & Ruegeria sp. LMB & 98 & Proteobacteria \\
\hline PL35(5) & KP236210.1 & Staphylococcus epidermidis strain 0074 & 99 & Firmicutes \\
\hline PL35(6) & KC429803.1 & Ruegeria sp. JZ10IS2 & 95 & Proteobacteria \\
\hline PL40(1) & EU685817.1 & Bacillus sp. PK-8 & 96 & Firmicutes \\
\hline PL40(2) & KM083802.1 & Staphylococcus sp. JPR7 & 92 & Firmicutes \\
\hline PL40(3) & KT200230.1 & Bacillus sp. K21 & 98 & Firmicutes \\
\hline PL40(4) & KR006239.1 & Acinetobacter gyllenbergii strain 8T & 99 & Proteobacteria \\
\hline PL45(1) & KX155823.1 & Bacillus amyloliquefaciens strain HQB606 & 98 & Firmicutes \\
\hline \multicolumn{5}{|c|}{ P. sinensis coral } \\
\hline PS25(1) & FJ157159.1 & Halobacillus trueperi strain B6 & 98 & Firmicutes \\
\hline PS25(2) & KC429883.1 & Ruegeria sp. JZ10ML44 & 99 & Proteobacteria \\
\hline PS25(3) & DQ868675.1 & Bacillus sp. SMB9 & 99 & Firmicutes \\
\hline PS25(4) & FJ161368.1 & Ruegeria atlantica strain D7087 & 94 & Proteobacteria \\
\hline PS25(5) & HE584770.1 & Phaeobacter daeponensis isolate AP12 & 99 & Proteobacteria \\
\hline PS25(6) & $\mathrm{AB} 617555.1$ & Bacillus sp. T10-2M & 99 & Firmicutes \\
\hline PS30(1) & KM010131.1 & Sediminibacillus halophilus strain muz2b & 87 & Firmicutes \\
\hline PS30(2) & KC751078.1 & Pseudovibrio denitrificans strain A-25 & 98 & Proteobacteria \\
\hline PS30(3) & KF282363.1 & Alteromonadaceae bacterium GUDS1097 & 98 & Proteobacteria \\
\hline PS30(4) & KJ645918.1 & Corynebacterium glycinophilum strain AJ 3170 & 96 & Actinobacteria \\
\hline PS30(5) & KF933616.1 & Virgibacillus pantothenticus strain BDH21 & 99 & Firmicutes \\
\hline PS35(1) & HQ908670.1 & Ruegeria lacuscaerulensis strain F71078 & 99 & Proteobacteria \\
\hline PS35(2) & JX317743.1 & Aquimarina sp. RKVR24 & 99 & Bacteroidetes \\
\hline PS35(3) & FJ952779.1 & Microbulbifer sp. 2 ta13 & 98 & Proteobacteria \\
\hline PS35(4) & KU321281.1 & Pseudovibrio sp. RKEM 536 & 99 & Proteobacteria \\
\hline PS35(5) & DQ448795.1 & Bacillus sp. CNJ901 PL04 & 98 & Firmicutes \\
\hline PS35(6) & NR_118542.1 & Phaeobacter caeruleus strain DSM 24564 & 99 & Proteobacteria \\
\hline
\end{tabular}

Of each coral species, data were ordered by cultured temperature and within the same temperature, data were ordered by relative abundance. The first 2 letters of cultured bacterial ID (ID) represent coral species, the following number is the lowest cultured temperature that the colony was found, and the number in parenthesis represents a dilution where the colony was taken from. Only distinct morphology colonies with at least $9 \%$ relative abundance on individually cultured SNA plates were sequenced, and only cultured bacterial IDs that received the significant E-value cutoffs by BLASTN were displayed. 


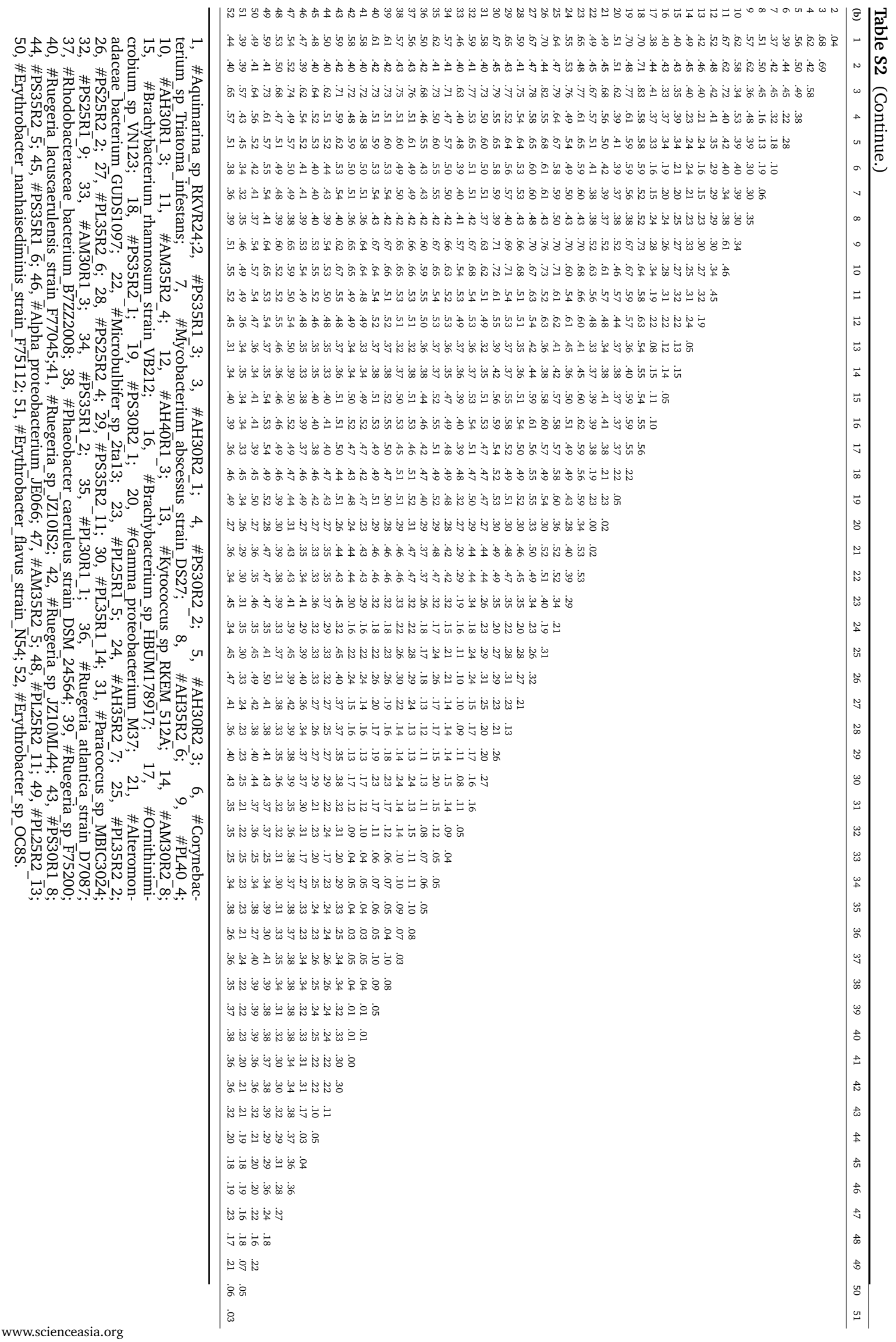

